\title{
Involvement of Up-regulation of Death Receptors and Bim in Hispolon-mediated TNF-related Apoptosis-inducing Ligand Sensitization in Human Renal Carcinoma
}

\author{
Jung Mi Yun, Kyoung-jin Min, Taeg Kyu Kwon \\ Department of Immunology, School of Medicine, Keimyung University, Daegu, Korea
}

\begin{abstract}
Background: Hispolon has been shown to possess antitumor effects in various cancer cells. However, the underlying mechanisms are not fully understood. In this study, we evaluated the sensitizing effect of hispolon on TNF-related apoptosis-inducing ligand (TRAIL)-mediated apoptosis in human renal carcinoma cells.

Methods: Apoptosis was analyzed by using cell-based cytometer. The mRNA levels were assessed by reverse transcription-PCR. Bax activation was determined by oligomerization and fluorescence-activated cell sorting with Bax-NT monoclonal antibody. The protein expression was measured by Western blotting.

Results: Hispolon induced up-regulation of Bim and death receptors expression at the post-translational level.

Conclusions: Hispolon enhanced TRAIL-mediated apoptosis in renal carcinoma cells, but not in normal cells.

(J Cancer Prev 2019;24:155-162)
\end{abstract}

Key Words: Hispolon, TNF-related apoptosis-inducing ligand, Apoptosis, Death receptors, Bim

\section{INTRODUCTION}

Hispolon is an active phenol compound that is isolated from Phellinus linteus. It has various biological functions including anti-inflammatory, anti-oxidant, anti-proliferative, and anti-tumor effects [1-5]. Anti-tumor effect of hispolon has been shown through inhibition of cell growth, induction of cell cycle arrest and apoptosis, and inhibition of metastasis in various types of cancer [3,5-9]. Down-regulation of G1/S transition-related proteins [6,10], modulation of extracellular signal-regulated kinase phosphorylation [1], and reactive oxygen species-mediated mitochondria damage [9] were proposed to involvement in anti-cancer effect by hispolon. However, there have been no reports on the anti-tumor effects of hispolon in renal carcinoma cells.

TNF-related apoptosis-inducing ligand (TRAIL), one of the TNF ligand family members, induces apoptosis in a wide range of human cancer cells [11,12], but not normal cells [13,14]. However, cancer cells frequently acquire TRAIL resistance through a variety of mechanisms. Downregulation of death receptors (DRs) expression and pro-apoptotic proteins (Bax and Bak), upregulation of decoy receptors (DcR1 and DcR2) and anti-apoptotic proteins (cFLIP, XIAP, and Mcl-1), and activation of survival signal pathways [15-19] can lead to TRAIL resistance. To overcome these limitations, combination treatment with TRAIL sensitizer could overcome TRAIL resistance.

In this study, we investigated whether hispolon enhances human renal carcinoma Caki cells to TRAIL-induced apoptotic cell death. We found that hispolon enhances TRAIL-mediated apoptosis in renal carcinoma cells, but not in normal cells through the up-regulation of DR and pro-apoptotic protein Bim expression.

Received August 28, 2019, Revised September 18, 2019, Accepted September 20, 2019

Correspondence to: Taeg Kyu Kwon

E-mail: kwontk@dsmc.or.kr, ORCID: Taeg Kyu Kwon, https://orcid.org/0000-0003-1204-2059

Copyright (C) 2019 Korean Society of Cancer Prevention

(c) This is an Open Access article distributed under the terms of the Creative Commons Attribution Non-Commercial License (http://creativecommons.org/licenses/by-nc/4.0) which permits unrestricted non-commercial use, distribution, and reproduction in any medium, provided the original work is properly cited. 


\section{MATERIALS AND METHODS}

\section{Cell culture and materials}

American Type Culture Collection (Manassas, VA, USA) supplied the all cells and the transformed mouse kidney cells (TCMK-1) was a gift from Dr. TJ Lee (Yeungnam University, Korea). The cells were cultured using Dulbecco's modified Eagle's medium containing $10 \% \mathrm{FBS}, 20 \mathrm{mM}$ HEPES buffer and $100 \mu \mathrm{g} / \mathrm{mL}$ gentamycin. Hispolon was purchased from ENZO life Science (Farmingdale, NY, USA). The recombinant human TRAIL was purchased from KOMA Biotech (Seoul, Korea). Anti-DR5 (1:700, \#8074), Bcl-xL (1:700, \#2764), and anti-PARP (1:700, \#9542) antibodies were purchased from Cell Signaling Technology (Beverly, MA, USA). Anti-DR4 (1:1,000, ab8414), and anti-cIAP1 (1:700, ab154525), antibodies were purchased from Abcam (Cambridge, UK). Anti-c-FLIP (1:700, ALX-804-961-0100) antibody was obtained from Enzo Life Sciences. Anti-Mcl-1 (1:700, sc-819) and anti-cIAP2 (1:700, sc7944) antibodies were purchased from Santa Cruz Biotechnology (Santa Cruz, CA, USA). Anti-XIAP $(1: 1,000,610762)$ antibody and anti-Bim (1:700, AB17003) antibodies were purchased from BD Biosciences (San Jose, CA, USA). Cyclohexamide and other reagents were purchased from Sigma Chemical Co. (St. Louis, MO, USA).

\section{Flow cytometry analysis}

Cells were harvested and suspended in $100 \mu \mathrm{L}$ of PBS, and then added to $200 \mu \mathrm{L}$ of $95 \%$ ethanol. After 1 hour, cells were incubated in RNase containing $1.12 \%$ sodium citrate buffer at $37^{\circ} \mathrm{C}$ for 30 minutes, and $50 \mu \mathrm{g} / \mathrm{mL}$ propidium iodide added. For detecting apoptotic cells, we used BD Accuri ${ }^{\mathrm{TM}}$ C6 flow cytometer (BD Biosciences).

\section{Western blotting}

Cells were lysed in RIPA lysis buffer (20 mM HEPES and 0.5\% Triton X-100, $\mathrm{pH} 7.6$ ) and were centrifuged at $12,000 \times$ gat $4^{\circ} \mathrm{C}$ for 15 minutes. After calculating protein amount using BCA solution, cell lysates were separated by 10\% SDS-PAGE. After transfer, proteins on the nitrocellulose membranes (GE Healthcare Life Science, Pittsburgh, PO, USA) was detected by specific antibody using an Immobilon Western Chemiluminescent HRP Substrate (EMD Millipore, Darmstadt, Germany).

\section{DAPI (4`6-diamidino-2-phenylindole) staining}

After fixation using $1 \%$ paraformaldehyde, cells were stained with $300 \mathrm{nM}$ DAPI solution (Roche, Basel, Switzerland) for 10 minutes. The nuclear condensation was detected by fluorescence microscope (Carl Zeiss, Jena, Germany).

\section{DNA fragmentation and DEVDase activity assay}

Cells were incubated with reaction buffer containing acetyl-Asp-Glu-Val-Asp p-nitroanilide (Ac-DEVD-pNA) substrate for caspase 3. To measure DNA fragmentation, we used cell death detection ELISA plus kit (Boehringer Mannheim, Indianapolis, IN, USA) according to the manufacturer's recommendations, and analyzed by spectrophotometry (BMG Labtech, Ortenberg, Germany).

\section{Determination for the mitochondrial membrane potential by rhodamine 123}

Cells were incubated with rhodamine $123(5 \mu \mathrm{M}$; Molecular Probes Inc., Eugene, OR, USA) for 5 minutes in the dark at $37^{\circ} \mathrm{C}$, and washed with PBS. Cells were suspended in PBS, and was analyzed using a flow cytometer (BD Biosciences).

\section{Reverse transcription-PCR}

Using TriZol reagent (Life Technologies, Gaithersburg, MD, USA), we obtained total RNA. We prepared the CDNA using M-MLV reverse transcriptase (Gibco-BRL, Gaithersburg, MD, USA), and we performed PCR using Blend Taq DNA polymerase (Toyobo, Osaka, Japan) with primers targeting DR4, DR5, and actin [20]. The amplified products were detected using 1.5\% agarose gels under UV light.

\section{Analysis of cytochrome $c$ release}

The cells were lysed for 2 minutes in $80 \mu \mathrm{L}$ ice-cold lysis buffer. After centrifuging at $12,000 \times g$ at $4^{\circ} \mathrm{C}$ for 10 minutes, we obtained the supernatants (cytosolic extracts free of mitochondria) and the pellets (fraction that contains mitochondria).

\section{Assay for Bax activation and oligomerization}

After fixing using $4 \%$ paraformaldehyde for 30 minutes, and cells were incubated for 1 hour at $4^{\circ} \mathrm{C}$ with the Bax-NT antibody (1:500; BD Biosciences) in PBS/1\% FCS (Gibco, Carlsbad, CA, USA) $+0.1 \%$ saponine (Sigma Chemical Co.). After incubation with the secondary antibody, washing and re-suspension in PBS/1\% FCS, and cells were measured by flow cytometry. For Bax oligomerization, the cells were suspended by conjugation buffer with $10 \mathrm{mM}$ EDTA containing $0.2 \mathrm{mM}$ bismaleimide (Thermo Scientific, Hudson, NH, USA) at room temperature for 1 hour and then extracted by lysis buffer for Western blot analysis. 


\section{Statistical analysis}

The data were analyzed using a one-way ANOVA and post-hoc comparisons (Student-Newman-Keuls) using the IBM SPSS ver. 22.0 software (IBM Corp., Armonk, NY, USA).

\section{RESULTS}

\section{Combination with hispolon and TNF-related} apoptosis-inducing ligand induces apoptosis

We investigated whether sub-lethal concentrations of hispolon enhances TRAIL-mediated apoptosis in human renal carcinoma Caki cells. Apoptotic cell death was not significantly induced by adding either hispolon or TRAIL alone (Fig. 1A). Combination of hispolon and TRAIL resulted in increase of sub G1 population and PARP cleavage in a dose-dependent manner, and induced morphological changes (cell body shrinkage and cell detachment) (Fig. 1A and 1B). Next, we examined whether combination of hispolon and TRAIL induces chromosomal condensation and DNA fragmentation. Combination of hispolon and TRAIL induced nuclear condensation and cytoplasmic histone-associated DNA fragments (Fig. 1C and 1D). These results indicate that hispolon

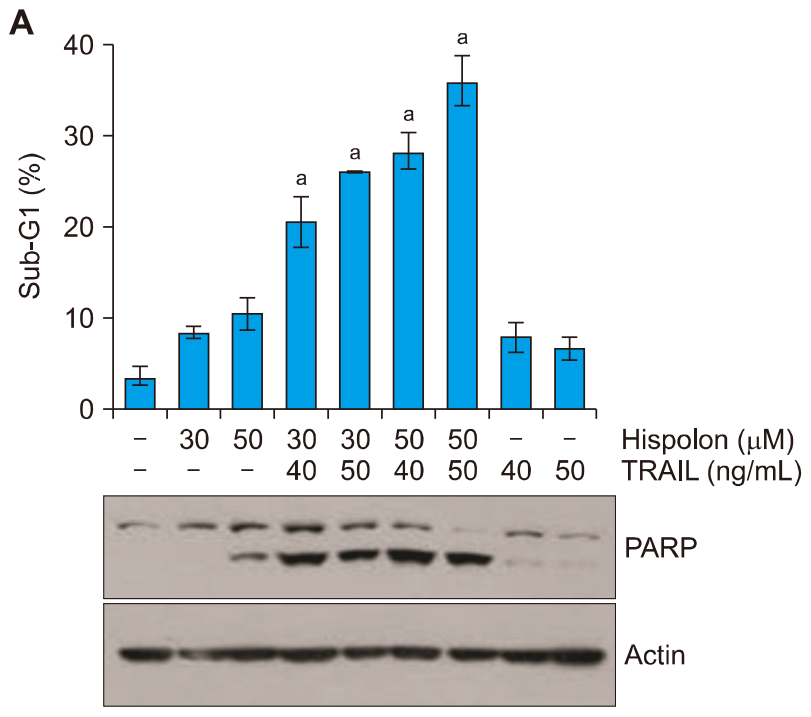

B

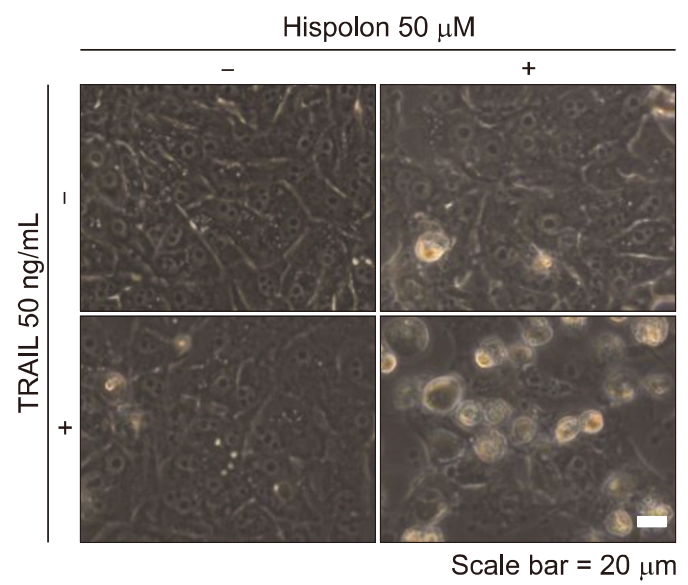

C

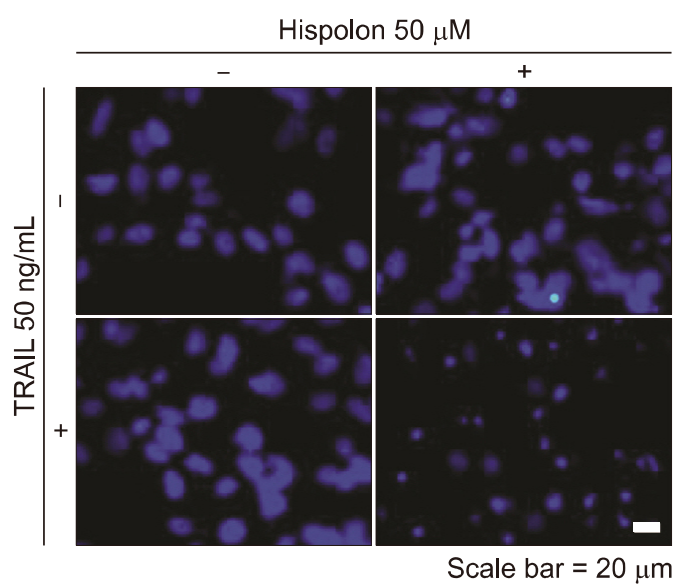

D

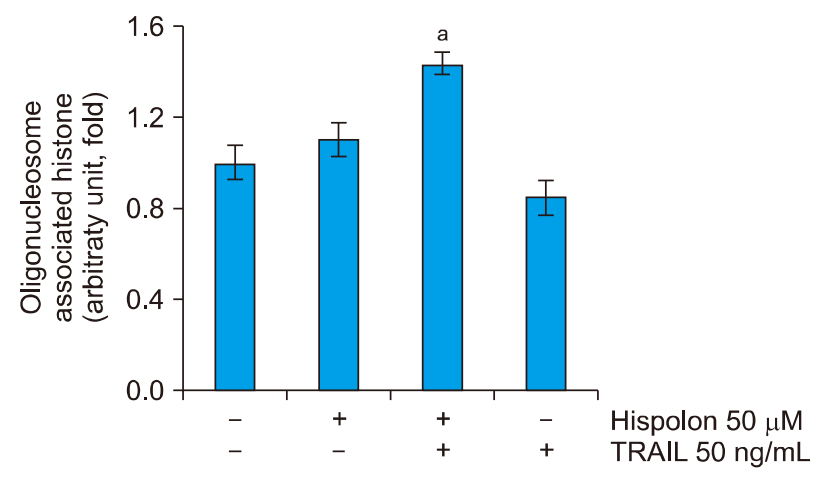

Figure 1. Hispolon enhances TNF-related apoptosis-inducing ligand (TRAIL)-induced apoptosis. (A) Caki cells were treated with $40 \mathrm{or} 50 \mathrm{ng} / \mathrm{mL}$ TRAIL in the presence or absence of the indicated concentrations of hispolon for 24 hours. The sub-G1 fraction was measured by flow cytometry as an indicator of the level of apoptosis. The protein expression levels of PARP and actin were determined by Western blotting. The level of actin was used as a loading control. (B) The cell morphology was examined using interference light microscopy. (C) The condensation and fragmentation of the nuclei were detected by 4',6-diamidino-2-phenylindole staining. The cytoplasmic histone-associated DNA fragments were determined by a DNA fragmentation detection kit (D). The values in panel A and D represent the mean \pm SD from three independent samples. ${ }^{a} P<0.01$ compared to the control. 
A

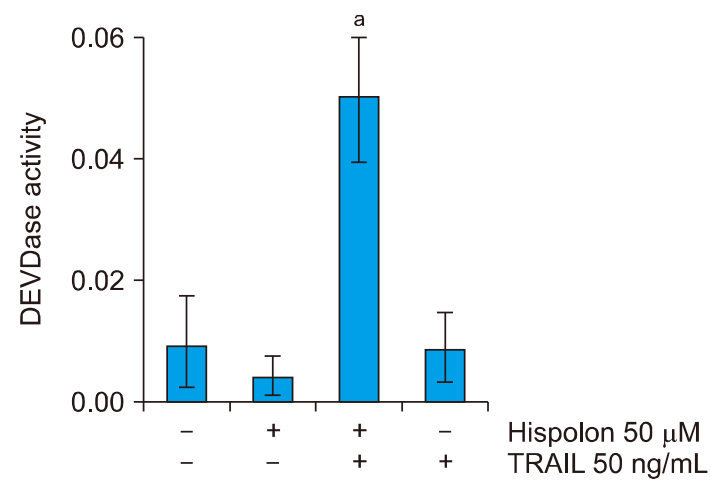

B

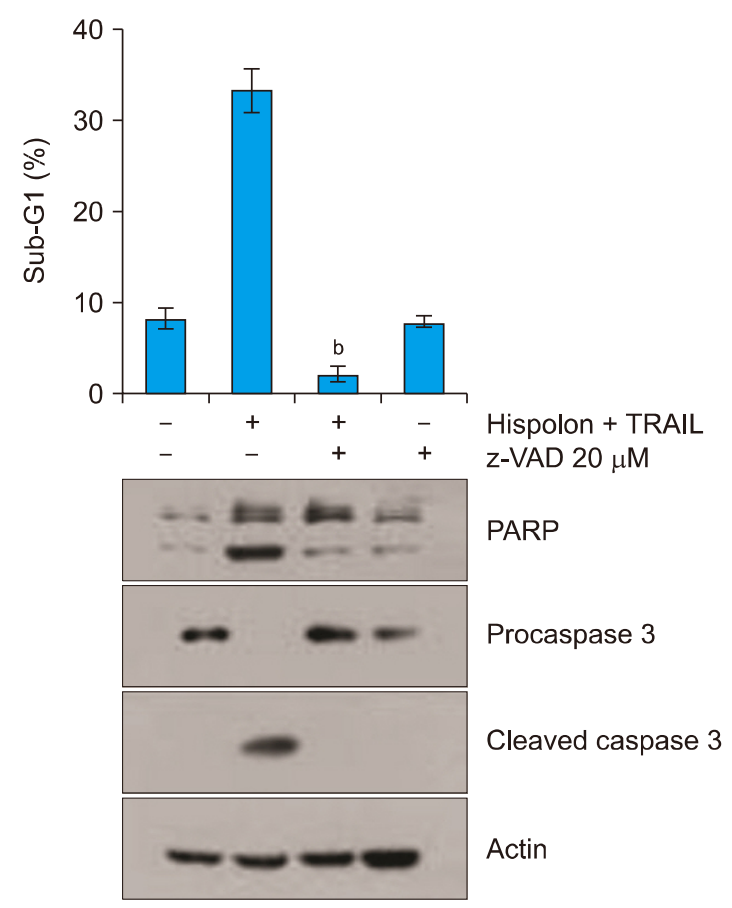

Figure 2. Combined treatment with hispolon and TNF-related apoptosis-inducing ligand (TRAIL) increases caspase activity. (A) Caki cells were treated with $50 \mathrm{ng} / \mathrm{mL}$ TRAIL in the presence or absence of $50 \mu \mathrm{M}$ hispolon for 24 hours. Caspase activities were determined with colorimetric assays using caspase-3 (DEVDase) assay kits. (B) Caki cells were treated with $50 \mu \mathrm{M}$ hispolon plus $50 \mathrm{ng} / \mathrm{mL}$ TRAIL for 24 hours in the presence or absence of $20 \mu \mathrm{M} \mathrm{z}$-VAD-fmk (z-VAD). The sub-G1 fraction was measured by flow cytometry. The protein expression levels of PARP, procaspase-3, cleaved caspase-3 and actin were determined by Western blotting. The level of actin was used as a loading control. The values in panel A and B represent the mean \pm SD from three independent samples. ${ }^{a} P<0.01$ compared to the control. ${ }^{\mathrm{b}} P<0.01$ compared to the co-treatment of hispolon and TRAIL.
A

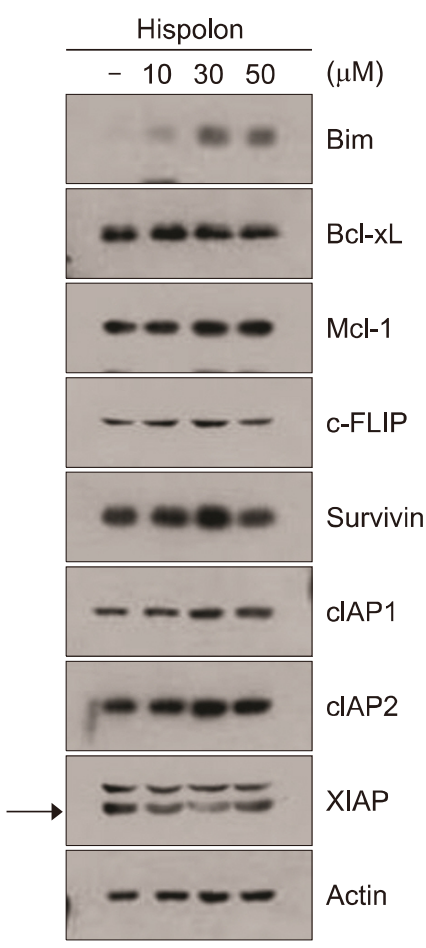

B

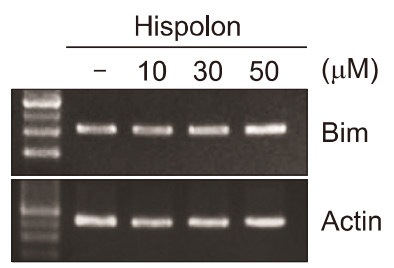

Figure 3. Hispolon induces up-regulation of Bim expression. Caki cells were treated with the indicated concentrations of hispolon for 24 hours. (A) The protein expression levels of Bim, Bcl-xL, Mcl-1, c-FLIP, survivin, cIAP1, cIAP2, XIAP, and actin were determined by Western blotting. (B) The mRNA expression levels of Bim and actin were determined by reverse transcription-PCR. The level of actin was used as a loading control.

enhances TRAIL-induced apoptosis.

2. Combined treatment with hispolon and TNF-related apoptosis-inducing ligand induces activation of caspase in renal carcinoma Caki cells

We performed further analysis for determination of whether combination of hispolon and TRAIL affects activation of caspases. As shown in Figure 2A, hispolon plus TRAIL increased caspase activity. Furthermore, pharmacological inhibition of pan-caspase with z-VAD markedly inhibited apoptosis, and blocked cleavage of PARP and procaspase in hispolon plus TRAIL-treated cells and (Fig. 2B). Therefore, these data indicate that combination of hispolon and TRAIL induces caspase-dependent apoptosis in human renal carcinoma Caki cells. 


\section{Combination of hispolon and TNF-related apoptosis-} inducing ligand induces modulation of apoptosis related proteins expression and release of cytochrome $c$ in Caki cells

Next, we examined whether modulation of apoptosis-related proteins expression allows induction of cell death in combination of hispolon and TRAIL-treated cells. Hispolon induced upregulation of proapoptotic protein Bim expression, whereas other proteins (Bcl-xL, Mcl-1, c-FLIP, survivin, cIAP1/2, and XIAP) did not change (Fig. 3A). Next, we investigated whether hispolon induces Bim mRNA expression. As shown in Figure 3B, mRNA expression of Bim was not changed in hispolon-treated cells.

To investigated the involvement of the mitochondrial death pathway, we analyzed the mitochondrial membrane potential (MMP) and cytochrome $c$ release. Hispolon drastically reduced the MMP levels (Fig. 4A). In addition, Hispolon induced cytochrome $c$ release from mitochondria to cytosol (Fig. 4B). We therefore performed the activation of Bax, which is an essential player in a mitochondria mediated apoptosis [21]. As shown in Figure 4C and 4D, we detected the conformational changes of Bax (active-Bax) and Bax oligomerization in hispolon-treated cells.
These data suggest that hispolon induces mitochondriamediated apoptosis through Bax activation.

\section{Hispolon increases up-regulation of components of death-inducing signaling complex}

Formation of the death-inducing signaling complex is a pivotal step on TRAIL-mediated apoptosis [22,23]. Therefore, we investigated whether hispolon regulates expression of DRs. We found that Caki cells exposed to hispolon drastically induced DR4/5 expression (Fig. 5A). Next, we investigated whether hispolon induces DR4 and DR5 expression at the transcriptional level. In renal carcinoma Caki cells, no significant increases in DR4/5 mRNA were detectable (Fig. 5B). Therefore, we tested the possibility of post-translational modulation. To identify this possibility, Caki cells were treated with or without hispolon in the presence of cyclohexamide. Hispolon increased DR4/5 protein stability in Caki cells (Fig. 5C). Next, we investigated whether hispolon modulates the ubiquitination of total proteins. However, we did not detect significant change of ubiquitination (Fig. 5D). These results indicate that hispolon induces upregulation of DRs protein expression at the post-translational levels, and hispolon-mediated DRs up-regulation is involved in
A

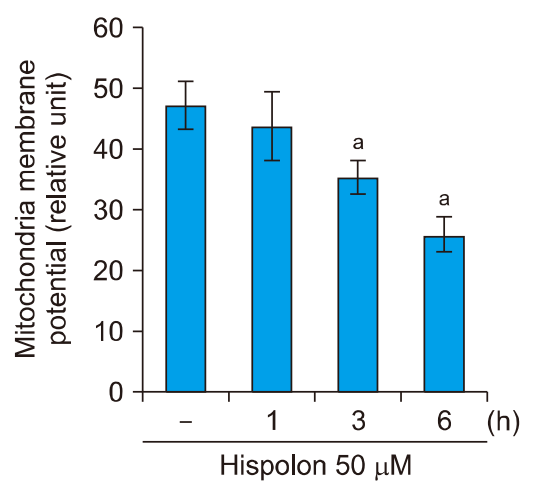

C

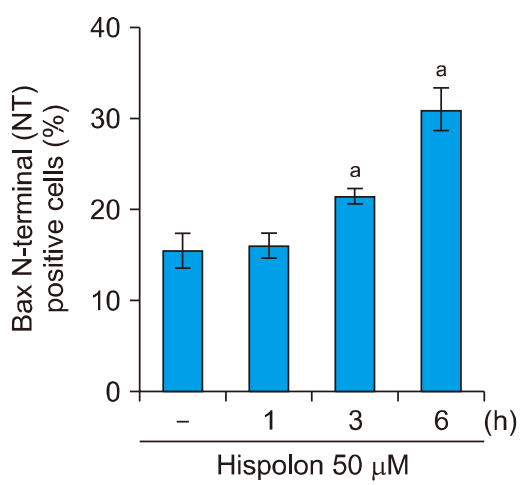

B

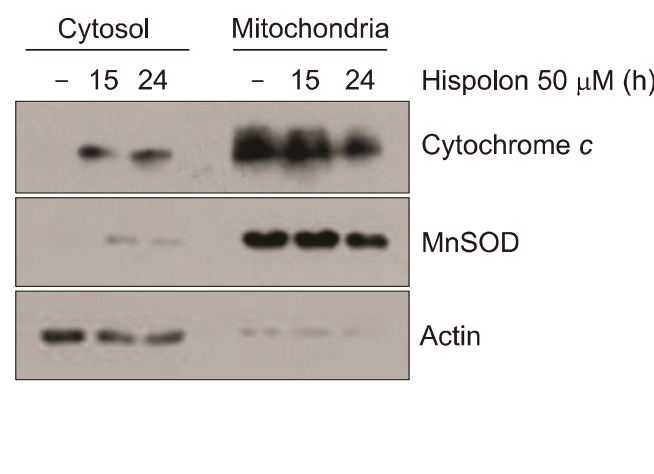

D

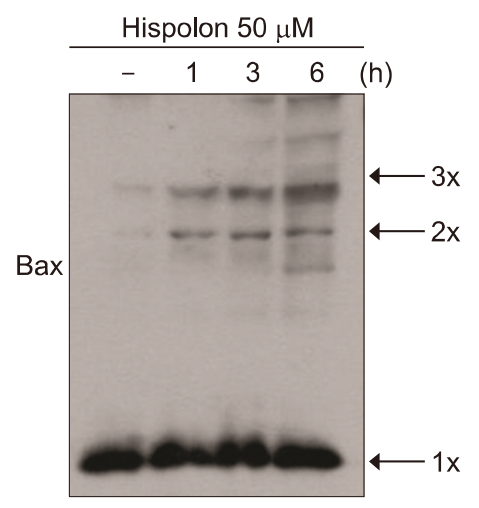

Figure 4. Hispolon reduces mitochondria membrane potential. (A) Caki cells were treated with $50 \mu \mathrm{M}$ hispolon for the indicated time periods. The mitochondrial membrane potential was measured using a flow cytometer. (B) Cytosolic extracts were prepared as described under Materials and Methods. The protein expression levels of cytochrome $c$ and MnSOD were determined by Western blotting. The level of MnSOD was used as a mitochondria fraction marker. (C) Cells were stained for active Bax using conformation-specific antibodies. The fluorescence intensity was detected by flow cytometry. (D) For Bax oligomerization assay, Bax monomers and oligomers were detected by Western blotting. The values in panel A and $C$ represent the mean \pm SD from three independent samples. ${ }^{\mathrm{a} P}<$ 0.01 compared to the control. 


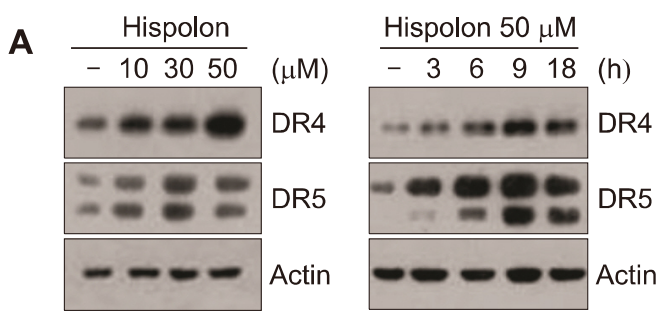

C

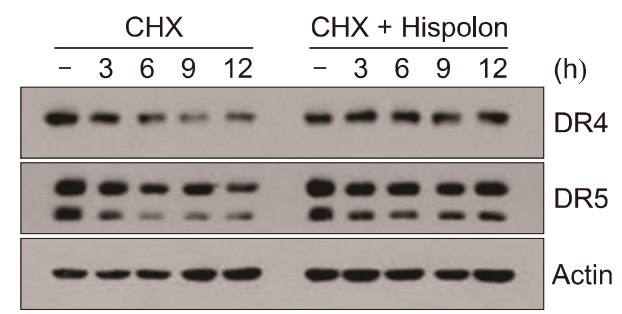

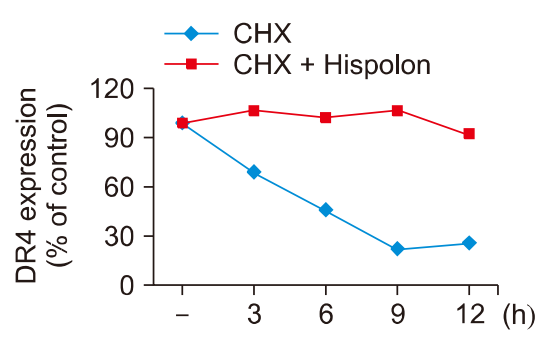

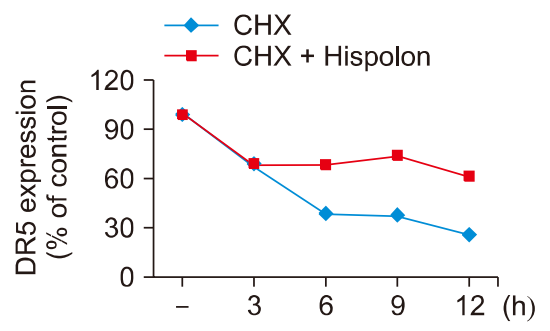

B

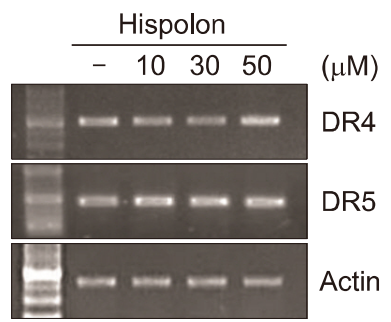

D

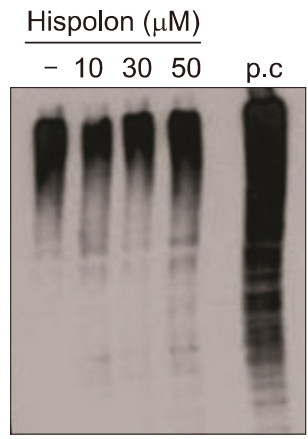

Figure 5. Hispolon induced up-regulation of DR4/5 expression at the post-translational levels. (A, B) Caki cells were treated with the indicated concentrations of hispolon for the indicated time periods. The protein and mRNA expression levels of DR4, DR5, and actin were determined by Western blotting and reverse transcription-PCR, respectively. The level of actin was used as a loading control. (C) Caki cells were treated with or without $50 \mu \mathrm{M}$ hispolon in the presence of cyclohexamide (CHX) $(20 \mu \mathrm{g} / \mathrm{mL})$ for the indicated time periods. The protein expression levels of DR4, DR5, and/or actin were determined by Western blotting. The level of actin was used as a loading control. The band intensities of DR4 and DR5 protein were measured using the public domain JAVA image-processing program ImageJ. (D) Caki cells were treated with the indicated concentrations of hispolon for 24 hours. The protein levels of ubiquitin were determined by Western blotting. p.c, positive control, $0.5 \mu \mathrm{M}$ MG132.

the effect of hispolon on TRAIL sensitization.

\section{Combined treatment with hispolon and TNF-related apoptosis-inducing ligand induces apoptosis in other renal cancer cells, but not normal cells}

To investigate the effect of combination with hispolon and TRAIL on cell death in other renal cancer cells, we used other renal cancer cells (ACHN and A498). ACHN and A498 cells, exposed to hisolon and TRAIL, efficiently increase apoptosis, and PARP cleavage (Fig. 6A and 6B). In contrast, normal cells (human skin fibroblast and normal TCMK-1) was not detectable any change of cell morphology and sub-G1 population in hispolon plus TRAIL-treated cells (Fig. 6C and 6D). These data indicate that combination with hispolon and TRAIL might induce apoptosis in cancer cells, but not normal cells.

\section{DISCUSSION}

Hispolon is known as a phenol compound which exhibits anticancer effects. However, there are no reports about the anticancer effect on renal carcinoma cells. In this study, we demonstrated that hispolon enhanced TRAIL-mediated apoptosis in renal cancer cells, but not normal cells. We found that the mechanism of hispolon-mediated TRAIL sensitization is associated with up-regulation of DRs protein stability and pro-apoptotic protein Bim expression. Moreover, hispolon induced loss of MMP and led to the release of cytochrome $c$ via Bax activation. These data support that hispolon could act as an attractive drug for TRAIL-sensitization.

Previous studies have shown that hispolon treatment leads to decreased expression of anti-apoptotic proteins, such as c-FLIP, Bcl-2, and Bcl-xL in colon cancer HCT116 [24]. However, hispolon 
A

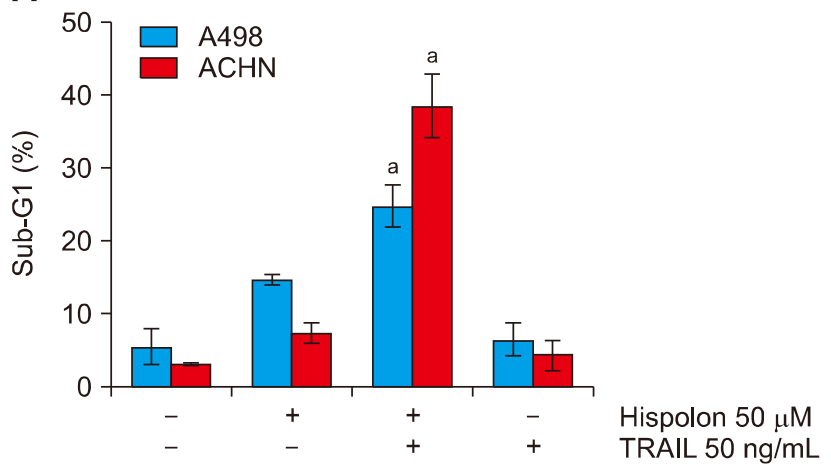

C

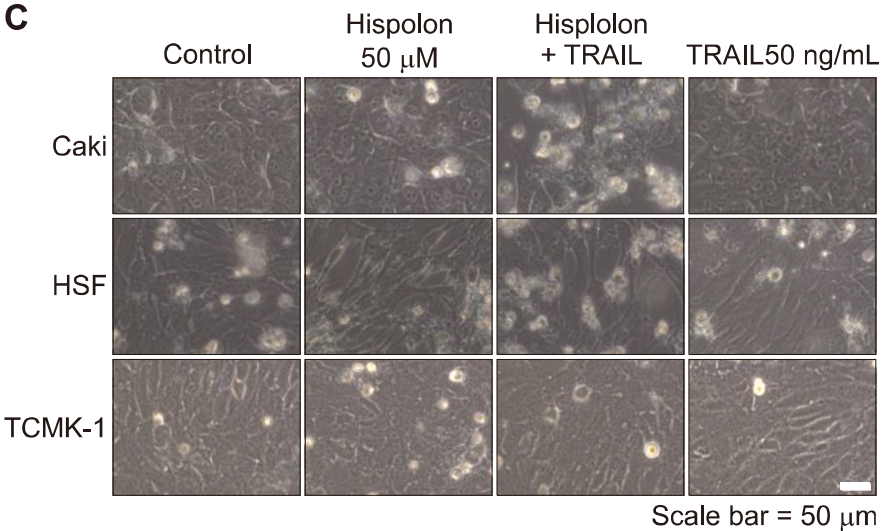

B

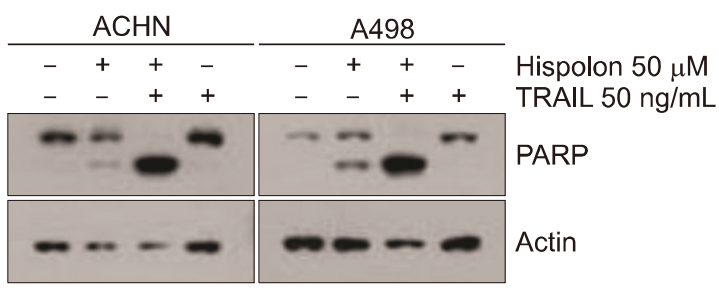

D

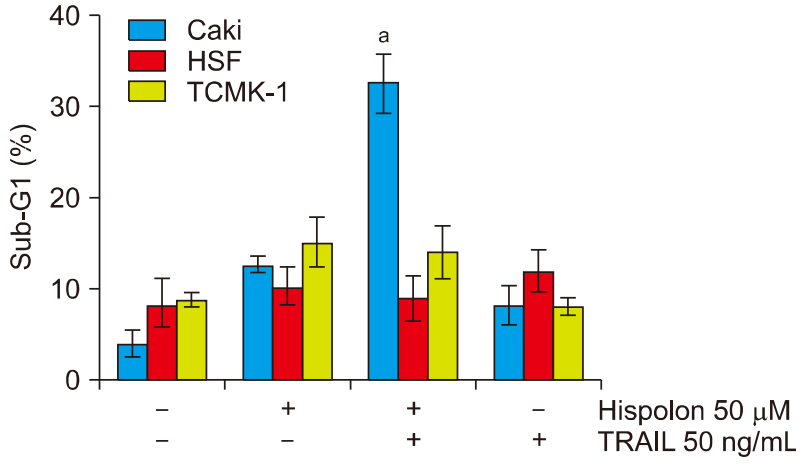

Figure 6. The effects of combined treatment with hispolon and TNF-related apoptosis-inducing ligand (TRAIL) on apoptosis in other renal carcinoma and normal cells. (A, B) Renal carcinoma (A498 and ACHN) cells were treated with $50 \mathrm{ng} / \mathrm{mL}$ TRAIL in the presence or absence of $50 \mu \mathrm{M}$ hispolon for 24 hours. The level of apoptosis was measured by the sub-G1 fraction using flow cytometry. The protein expression levels of PARP and actin were determined by Western blotting. The level of actin was used as a loading control. (C, D) Caki, human skin fibroblast, and transformed mouse kidney cells (TCMK-1) cells were treated with $50 \mathrm{ng} / \mathrm{mL}$ TRAIL in the presence or absence of $50 \mu \mathrm{M}$ hispolon for 24 hours. The cell morphology was examined using interference light microscopy (C). The level of apoptosis was analyzed by measuring the sub G1 fraction by flow cytometry (D). The values in panel A and D represent the mean \pm SD from three independent samples. ${ }^{a} F$ $<0.01$ compared to the control.

did not change these protein levels in Caki cells (Fig. 3). These results suggest that the regulation of apoptosis related proteins by hispolon is a cell type-specific. We observed that hispolon induced upregulation of Bim expression (Fig. 3). Bim protein, BCl-2 homology domain 3 (BH3) only protein, provokes apoptosis either by direct activation of pro-apoptotic Bax/Bak or by inhibiting anti-apoptotic protein function through $\mathrm{BH} 3$ domain [25]. To investigate the pathway(s) involved in hispolon-induced apoptosis of Caki cells, Bax-NT monoclonal antibody assay was performed to analyze the Bax activation. We found that hispolon enhanced the loss of mitochondrial membrane potential, suggesting that hispolon induces apoptosis through intrinsic apoptotic pathway.

The expression levels of DR $4 / 5$ protein are regulated by multiple mechanisms, such as transcriptional, translational, and post-translational regulation. Hispolon treatment had no effect on the expression levels of DR4/5 mRNA (Fig. 5B). Our data indicate hispolon-induced DR4/5 upregulation is shown to be related to the post-transcriptional regulation. We further found that hispolon markedly enhanced the stability of DR $4 / 5$ protein. These results suggest that hispolon-mediated DR4/5 upregulation is associated with post-translational regulation such as ubiquitinproteasome pathway or/and glycosylation [26]. Therefore, the mechanism of hispolon may upregulate DR $4 / 5$ remain unclear and require further investigation.

Collectively, these results suggest that hispolon enhances TRAIL-mediated apoptosis through the up-regulation of proapoptotic Bim protein and DRs expression in the human renal Caki cell lines. Combined treatment with hispolon and TRAIL also markedly induced apoptosis in other renal carcinoma, but not in normal cells. Therefore, hispolon may be effectively used as a sensitizer of TRAIL, however, further animal in vivo studies are 
needed to realize this combination anticancer therapy.

\section{ACKNOWLEDGMENTS}

This work was supported by an NRF grant funded by the Korea Government (MSIP) (2014R1A5A2010008).

\section{CONFLICT OF INTEREST}

No potential conflicts of interest were disclosed.

\section{REFERENCES}

1. Zhao Z, Sun YS, Chen W, Lv LX, Li YQ. Hispolon inhibits breast cancer cell migration by reversal of epithelial-to-mesenchymal transition via suppressing the ROS/ERK/Slug/E-cadherin pathway. Oncol Rep 2016;35:896-904.

2. Chang HY, Sheu MJ, Yang CH, Lu TC, Chang YS, Peng WH, et al. Analgesic effects and the mechanisms of anti-inflammation of hispolon in mice. Evid Based Complement Alternat Med 2011;2011:478246.

3. Huang GJ, Deng JS, Huang SS, Hu ML. Hispolon induces apoptosis and cell cycle arrest of human hepatocellular carcinoma Hep3B cells by modulating ERK phosphorylation. J Agric Food Chem 2011:59:7104-13.

4. Chen W, Zhao Z, Li L, Wu B, Chen SF, Zhou H, et al. Hispolon induces apoptosis in human gastric cancer cells through a ROSmediated mitochondrial pathway. Free Radic Biol Med 2008;45: 60-72.

5. Hsiao PC, Hsieh YH, Chow JM, Yang SF, Hsiao M, Hua KT, et al. Hispolon induces apoptosis through JNK1/2-mediated activation of a caspase-8, -9, and -3-dependent pathway in acute myeloid leukemia (AML) cells and inhibits AML xenograft tumor growth in vivo. J Agric Food Chem 2013;61:10063-73.

6. Arcella A, Oliva MA, Sanchez M, Staffieri S, Esposito V, Giangaspero F, et al. Effects of hispolon on glioblastoma cell growth. Environ Toxicol 2017;32;2113-23.

7. Chen YC, Chang HY, Deng JS, Chen JJ, Huang SS, Lin IH, et al. Hispolon from Phellinus linteus induces G0/G1 cell cycle arrest and apoptosis in NB4 human leukaemia cells. Am J Chin Med 2013:41:1439-57.

8. Jang EH, Jang SY, Cho IH, Hong D, Jung B, Park MJ, et al. Hispolon inhibits the growth of estrogen receptor positive human breast cancer cells through modulation of estrogen receptor alpha. Biochem Biophys Res Commun 2015;463:917-22.

9. Hsin MC, Hsieh YH, Wang PH, Ko JL, Hsin IL, Yang SF. Hispolon suppresses metastasis via autophagic degradation of cathepsin $\mathrm{S}$ in cervical cancer cells. Cell Death Dis 2017;8:e3089.

10. Wu Q, Kang Y, Zhang H, Wang H, Liu Y, Wang J. The anticancer effects of hispolon on lung cancer cells. Biochem Biophys Res Commun 2014:453:385-91.
11. Mellier G, Huang S, Shenoy K, Pervaiz S. TRAILing death in cancer. Mol Aspects Med 2010;31:93-112.

12. Nazim UM, Rasheduzzaman M, Lee YJ, Seol DW, Park SY. Enhancement of TRAIL-induced apoptosis by 5-fluorouracil requires activating Bax and p53 pathways in TRAIL-resistant lung cancers. Oncotarget 2017;8:18095-105.

13. Ashkenazi A, Dixit VM. Death receptors: signaling and modulation. Science 1998;281:1305-8.

14. Wang S, El-Deiry WS. TRAIL and apoptosis induction by TNF-family death receptors. Oncogene 2003;22:8628-33.

15. Jin Z, McDonald ER 3rd, Dicker DT, El-Deiry WS. Deficient tumor necrosis factor-related apoptosis-inducing ligand (TRAIL) death receptor transport to the cell surface in human colon cancer cells selected for resistance to TRAIL-induced apoptosis. J Biol Chem 2004:279:35829-39.

16. Kelly MM, Hoel BD, Voelkel-Johnson C. Doxorubicin pretreatment sensitizes prostate cancer cell lines to TRAIL induced apoptosis which correlates with the loss of c-FLIP expression. Cancer Biol Ther 2002;1:520-7.

17. Ng CP, Zisman A, Bonavida B. Synergy is achieved by complementation with Apo2L/TRAIL and actinomycin D in Apo2L/ TRAIL-mediated apoptosis of prostate cancer cells: role of XIAP in resistance. Prostate 2002;53:286-99.

18. Walczak H, Bouchon A, Stahl H, Krammer PH. Tumor necrosis factor-related apoptosis-inducing ligand retains its apoptosis-inducing capacity on Bcl-2- or Bcl-xL-overexpressing chemotherapyresistant tumor cells. Cancer Res 2000;60:3051-7.

19. Zhang Y, Zhang B. TRAIL resistance of breast cancer cells is associated with constitutive endocytosis of death receptors 4 and 5 . Mol Cancer Res 2008;6:1861-71.

20. Jung KJ, Min KJ, Bae JH, Kwon TK. Carnosic acid sensitized TRAIL-mediated apoptosis through down-regulation of c-FLIP and $\mathrm{Bcl}-2$ expression at the post translational levels and CHOPdependent up-regulation of DR5, Bim, and PUMA expression in human carcinoma caki cells. Oncotarget 2015;6:1556-68.

21. Hsu YT, Youle RJ. Bax in murine thymus is a soluble monomeric protein that displays differential detergent-induced conformations. J Biol Chem 1998:273:10777-83.

22. Bodmer JL, Holler N, Reynard S, Vinciguerra P, Schneider P, Juo P, et al. TRAIL receptor-2 signals apoptosis through FADD and caspase-8. Nat Cell Biol 2000;2:241-3.

23. Kischkel FC, Lawrence DA, Chuntharapai A, Schow P, Kim KJ, Ashkenazi A. Apo2L/TRAIL-dependent recruitment of endogenous FADD and caspase- 8 to death receptors 4 and 5. Immunity 2000; 12:611-20.

24. Kim JH, Kim YC, Park B. Hispolon from Phellinus linteus induces apoptosis and sensitizes human cancer cells to the tumor necrosis factor-related apoptosis-inducing ligand through upregulation of death receptors. Oncol Rep 2016;35:1020-6.

25. Lomonosova E, Chinnadurai G. BH3-only proteins in apoptosis and beyond: an overview. Oncogene 2008:27 Suppl 1:S2-19.

26. Min KJ, Woo SM, Shahriyar SA, Kwon TK. Elucidation for modulation of death receptor (DR) 5 to strengthen apoptotic signals in cancer cells. Arch Pharm Res 2019:42:88-100. 